\title{
Glukokortikoidinjeksjoner i behandling av sesongallergi
}

\author{
Glukokortikoidinjeksjoner er blitt brukt i behandling av pollenallergi \\ i mer enn 50 år. Behandlingen er enkel og etterspurt, men er den også \\ effektiv og sikker?
}

Sesongallergikernes inntog på venterommene er et sikkert vårtegn for leger i allmennpraksis. De fleste pasientene har milde til moderate plager som $i$ henhold til internasjonale $(1-3)$ og norske (4) veiledere kan behandles med systemiske antihistaminer eller topikale antihistaminer/glukokortikoider i form av nesespray og kanskje også øyedråper. Ved manglende symptomlindring tilbys noen av disse pasientene injeksjonsbehandling med glukokortikoid (1-4). Slike injeksjoner omsettes i Norge i et omfang tilsvarende ca. tre definerte døgndoser per 1000 personer per døgn (5), men siden mye av dette trolig brukes ved andre indikasjoner enn sesongallergi, er det vanskelig å ha en oppfatning om hvor utbredt denne behandlingen er. Behandlingsprinsippet er omdiskutert (6), og vi skal i det følgende kort diskutere dokumentasjonen for bruk av glukokortikoider som injeksjon ved indikasjonen sesongallergi. Basis for denne gjennomgangen er datasøk i PubMed med søkeordene «hay fever», «allergic rhinitis», «pollinosis», «intramuscular injection», «glucocorticoids», «bethametasone», «triamcinolone» og «methylprednisolone». Vi har gjennomgått disse artiklene og deres referanselister samt forsøkt å innhente og evaluere alle relevante publiserte studier på feltet.

\section{Preparater}

Injiserbare glukokortikoider er en heterogen gruppe legemidler (tab 1). Noen av preparatene består av glukokortikoidet $\mathrm{i}$ originalformen, noen er blandinger av oppløste salter som hevdes å ha både umiddelbar og protrahert virkning, noen er formulert som estere og andre foreligger som acetonider (7). Formuleringene er sannsynligvis ment å ha en depoteffekt, slik at aktivt glukokortikoid skal avgis over tid og gi en mer langvarig farmakologisk effekt enn det som oppnås med glukokortikoidet i sin vanlige form. Påstander om spesielt lange virketider gjenfinnes i Norsk legemiddelhåndbok (8) og i preparatomtalene (tab 1). Det er imidlertid verdt å merke seg at påstandene savner dokumentasjon, og komparative studier av inhalasjonssteroider har for eksempel vist at triamcinolonacetonid både har en relativt høy biotilgjengelighet og en kort halveringstid i blod (9). Datasøk og henvendelser til produsentene har ikke frembrakt én eneste farmakokinetisk eller annen studie som viser at de injiserbare glukokortikoidene (tab 1) formidler effekter som kvalitativt eller kvantitativt avviker fra de som oppnås når glukokortikoidet gis peroralt $\mathrm{i}$ ekvipotente doser.

Det finnes ikke norske retningslinjer for behandling av sesongallergi. I Norsk elektronisk legehåndbok (NEL) sto det frem til nylig at intramuskulær glukokortikoidterapi var å anse som trygg og effektiv terapi som neppe førte til bivirkninger (4). I løpet av året er disse anbefalingene blitt endret $\mathrm{i}$ tråd med vårt syn.

\section{Studier}

Østergaard og medarbeidere publiserte i 2005 en systematisk oversikt over studier av injeksjoner med glukokortikoider i behandling av allergisk rhinitt (10). Ingen av de 18 studiene som ble inkludert i oversikten var publisert etter 1988. I tillegg til disse studiene har egne datasøk identifisert fire andre studier publisert i tidsrommet 1965-82 (11-14). I disse totalt 22 studiene undersøkte man effekten av metylprednisolonacetat (40-80 mg, en eller flere injeksjoner), betametasondipropionat/fosfat/acetat $(2-10$ $\mathrm{mg}$ ), triamcinolonacetonid (40-80 $\mathrm{mg}$, en eller flere injeksjoner) og deksametasonfosfat/acetat $(8-16 \mathrm{mg})$ som intramuskulære injeksjoner ved sesongallergi. Ni av de 22 studiene var randomiserte og dobbeltblindede; fire av de ni var placebokontrollerte og i fem sammenliknet man flere aktive behandlinger med randomiseringsprosedyre. To studier var enkeltblindede sammenlikningsstudier, og de resterende 11 studiene var åpne. Antallet inkluderte pasienter i studiene var totalt 1589 . De randomiserte og placebokontrollerte studiene inkluderte totalt 187 pasienter, noe som utgjør $12 \%$ av den totale studiepopulasjonen.

Den første av de placebokontrollerte studiene med randomiseringsprosedyre (15) er fra 1960. Her evaluerte man injeksjoner med totalt $240 \mathrm{mg}$ metylprednisolonacetat hos 95 pasienter over en toukers periode, og regis-

\author{
Marianne Aadal \\ marianneaadal@hotmail.com \\ Avdeling for klinisk farmakologi \\ St. Olavs hospital \\ og \\ Lundamo Legesenter \\ Melhus kommune

\section{Lars Slørdal} \\ Institutt for laboratoriemedisin, \\ barne- og kvinnesykdommer \\ Norges teknisk-naturvitenskapelige universitet \\ og \\ Avdeling for klinisk farmakologi \\ St. Olavs hospital
}

\section{HOVEDBUDSKAP}

Studier av eldre dato kan tyde på at injeksjoner med glukokortikoider ved pollenallergi har god umiddelbar symptomlindrende effekt

Det finnes ingen farmakokinetiske studier av behandlingen, terapiprinsippet er dårlig dokumentert, og vi vet lite om forekomsten av langtidsbivirkninger

Anvendelse av dette terapiprinsippet ved sesongallergi bør reduseres 
trerte - ikke overraskende, de store dosene tatt $\mathrm{i}$ betraktning - god symptomlindrende effekt. I de tre øvrige placebokontrollerte studiene, der man undersøkte effektene av triamcinolonacetonid $(40 \mathrm{mg})$, betametasondipropionat og fosfat $(5+2 \mathrm{mg}) \mathrm{og}$ metylprednisolonacetat $(80 \mathrm{mg})$ hos henholdsvis 38 (16), 30 (17) og 24 (18) pasienter, ble det også rapportert positive resultater av behandlingen, men i en av studiene (18) ble det målt symptomreduksjon som noen ganger både var kortvarig og av mer tvilsom klinisk betydning.

Kun én studie sammenliknet glukokortikoid til injeksjon med peroral behandling. Betametasondipropionat + acetat $(10+4 \mathrm{mg})$ ble sammenliknet med prednisolon $(7,5 \mathrm{mg}$ daglig i tre uker), uten at man fant noen forskjell i effekt (19). Den systematiske oversikten fra 2005 munnet ut $i$ en generell konklusjon om at glukokortikoidinjeksjoner ved sesongallergi hos voksne er en effektiv og trygg behandling (10).

\section{Tid til effekt og effektvarighet}

Tid til oppnådd effekt ble ikke rapportert i de placebokontrollerte studiene $(15-18)$. I tre sammenliknende studier med randomiseringsprosedyrer undersøkte man dette uten å påvise forskjell mellom virkestoffene, og effekten inntraff i løpet av 12 timer (10). Seks av de åpne studiene omtaler tid til effekt av metylprednisolon og triamcinolon, og i alle inntrer effekten i løpet av tre dager uten at noen av virkestoffene peker seg ut som mer hurtigvirkende enn andre $(10,12,14)$.

I tre av de fire placebokontrollerte studiene ble varigheten av den kliniske effekten av glukokortikoidinjeksjonene undersøkt, med en variasjon fra $>20$ dager til $>$ fire uker (16-18). Effekten varte fra fire timer til fem uker i de sammenliknende randomiserte kontrollerte studiene. I en av disse studiene undersøkte man effektvarigheten av triamcinolon og deksametason og fant at $66 \%$ av forsøkspersonene opplevde effekt i mindre enn fire dager. Det var ingen signifikant forskjell mellom gruppene (20). Effektvarigheten i de åpne studiene var fra 12 timer til flere måneder (10-14). Heller ikke her oppviste noen av virkestoffene lengre effektvarighet enn de andre, mens det ble sett store interindividuelle forskjeller i de enkelte studiene.

\section{Bivirkninger}

Rapportering av bivirkninger inngikk i 19 av de 22 inkluderte studiene. De registrerte bivirkningene omfattet blant annet flere tilfeller av menstruasjonsforstyrrelser samt smerte og subkutan atrofi på injeksjonsstedet (10, 12-14). I åtte av studiene ble det monitorert tegn til forstyrrelser i endogen kortisolregulering, og hos forsøkspersonene kunne det gå

Tabell 1 Injeksjonsglukokortikoider med markedsføringstillatelse i Norge. Som det fremgår av tabellen, savnes sentral informasjon om disse formuleringenes farmakokinetiske og -dynamiske egenskaper. Data bygger på opplysningene i preparatomtaler i Felleskatalogen og den fullstendige preparatomtalen godkjent av legemiddelmyndighetene («summary of product characteristics»/SPC) (7)

\begin{tabular}{|c|c|c|c|c|}
\hline Virkestoff & Salgsnavn & $\begin{array}{l}\text { Indikasjon } \\
\text { allergi/rhinitt }\end{array}$ & $\begin{array}{l}\text { Halveringstid } \\
\text { i blod }\end{array}$ & Virketid \\
\hline Metylprednisolonacetatester & Depo-Medrol & + & $2,4-4 t$ & - \\
\hline Metylprednisolon & Solu-Medrol & + & $2,4-4 t$ & - \\
\hline Triamcinolonacetonid & Kenakort-T & + & - & $>2-4$ uker \\
\hline Triamcinolonheksacetonid & Lederspan & - & - & $>4-6$ uker \\
\hline Betametason ${ }^{1}$ & $\begin{array}{l}\text { Celeston } \\
\text { Chronodose }\end{array}$ & + & $36-54 t$ & - \\
\hline
\end{tabular}

«En kombinert hurtigvirkende oppløsning og en protrahertvirkende suspensjon av betametasonsalter» (7)

fra en uke til en måned etter injeksjonsbehandlingen til endogen kortisolproduksjon var fullstendig normalisert (10). I to studier med til sammen 94 behandlede pasienter ble vekt og blodtrykk undersøkt uten at det ble funnet signifikante endringer (10). Oppfølgingstiden etter injeksjonsbehandlingen var generelt kort $(10,12-14)$.

Bivirkninger av systemiske glukokortikoider er vanligvis doseavhengige, og mange av bivirkningene, selv ved bruk av lave doser, øker med varigheten av behandlingen. Vanlige bivirkninger er tynn hud, utslett, utseende som ved Cushings syndrom, vektøkning, søvnforstyrrelser og humørforandringer. Psykiatriske forstyrrelser, kognitive endringer og en sjelden gang psykose, kan forekomme ved høye doser. Hyperglykemi og nyoppdaget diabetes mellitus er mer vanlig hos pasienter som i utgangspunktet har etablert diabetes mellitus eller risiko for dette. Man bør være tilbakeholden med systemiske glukokortikoider ved tilstander som diabetes mellitus, hypertensjon, dyslipidemi, hjertesvikt, katarakt eller glaukom, sår i øvre gastrointestinalkanal, utstrakt bruk av ikke-steroide antiinflammatoriske midler, infeksjon, lav beintetthet eller osteoporose. Bruk av systemiske glukokortikoider i svangerskapet og ammeperioden kan gi binyrebarksuppresjon hos barnet og bør derfor unngås. Ved behandling av barn kan veksthemming oppstå selv ved relativt lave doser (21). Absolutte kontraindikasjoner ved systemisk bruk av glukokortikoider inkluderer systemiske infeksjoner, kjent allergi mot innholdsstoffene og nylig gjennomgått vaksinasjon med levende virus (22).

\section{Diskusjon}

Injeksjoner med glukokortikoider er blitt brukt $\mathrm{i}$ behandling av sesongallergi i mer enn 50 år. De kliniske studiene av terapiprinsippet konkluderer nærmest entydig med at effekten av behandlingen er god. Studiene er gjennomgående av kort varighet og eldre dato, og kun fire av 22 studier med til sammen 187 pasienter - der 95 fikk metylprednisolon i doser de fleste i dag vil avstå fra å bruke - er gjort med randomisert, dobbeltblindet og placebokontrollert metodologi.

Siden sesongallergi er en kronisk intermitterende lidelse og pollensesongen for mange er lang, må man som behandler ta stilling til når og eventuelt hvor mange ganger glukokortikoidinjeksjoner kan gis. Her kommer studiene til kort; vi mangler data for å vurdere optimal behandlingsintensitet. Profylaktisk behandling med injeksjoner av glukokortikoider frarådes på generelt grunnlag (18). De store spennene i effektvarighet og det hyppige fraværet av blindings- og randomiseringsprosedyrer i studiene kan tyde på at de positive rapporterte virkningene i noen grad kan være uspesifikke glukokortikoideffekter med innslag av placebofenomener. Det finnes heller ikke dokumentasjon som tilsier at injiserte glukokortikoider virker kvalitativt eller kvantitativt forskjellig fra ekvipotente perorale doser. I en studie ble de to distribusjonsformene sammenliknet, men ingen forskjell i effekt ble funnet (19). Når det gjelder valg av preparat, synes det ellers ikke å være klinisk relevante forskjeller i effekt mellom de ulike depotformuleringene.

En internasjonal terapiretningslinje fra 2010 inneholder eksplisitte råd om å avstå fra injeksjonsbehandling med glukokortikoider til sesongallergikere på grunn av bivirkningsfaren (3). Det er viktig å minne om at injeksjonsterapi med glukokortikoider bygger på et utilstrekkelig vitenskapelig fundament, at bivirkningsforekomsten kan være betydelig, samt at injeksjonsterapi neppe gir symptomatiske effekter som ikke vel så enkelt kan oppnås med peroral terapi. Dette tilsier at man bør være tilbakeholden med å tilby slik behandling. 


\section{Marianne Aadal (f. 1977)}

er spesialist i allmennmedisin.

Forfatter har fylt ut ICMJE-skjemaet og oppgir ingen interessekonflikter.

\section{Lars Slørdal (f. 1955)}

er professor i farmakologi og overlege.

Forfatter har fylt ut ICMJE-skjemaet og oppgir ingen interessekonflikter.

\section{Litteratur}

1. van Cauwenberge $P$, Bachert $C$, Passalacqua $G$ et al. Consensus statement on the treatment of allergic rhinitis. Allergy 2000; 55: 116-34.

2. Scadding GK, Durham SR, Mirakian R et al. BSACl guidelines for the management of allergic and non-allergic rhinitis. Clin Exp Allergy 2008; 38 $19-42$.

3. Brozek JL, Bousquet J, Baena-Cagnani CE et al. Allergic Rhinitis and its Impact on Asthma (ARIA) guidelines: 2010 revision. J Allergy Clin Immunol 2010; 126: 466-76

4. Norsk elektronisk legehåndbok. Allergisk rhinitt. www.legehandboka.no/ (4.1.2013).

5. Nasjonalt folkehelseinstitutt. Legemiddelforbru ket i Norge 2007-2011. Legemiddelstatistikk 2012; nr. 1: 57-9.
6. Mygind N, Laursen LC, Dahl M. Systemic corticosteroid treatment for seasonal allergic rhinitis: a common but poorly documented therapy. Allergy 2000; 55: 11-5

7. Felleskatalogen. www.felleskatalogen.no/medisin (14.12.2012).

8. Norsk legemiddelhåndbok

http://legemiddelhandboka.no/Legemidler/48394 (20.6.2010).

9. Derendorf H, Hochhaus G, Meibohm B et al. Pharmacokinetics and pharmacodynamics of inhaled corticosteroids. J Allergy Clin Immunol 1998; 101. S440-6.

10. Østergaard MS, Østrem A, Söderström M. Hay fever and a single intramuscular injection of corticosteroid: a systematic review. Prim Care Respir J 2005: 14: 124-30.

11. Ashoor AA, Ahmed M. Effects of intramuscular depot-corticosteroid on the nasal mucosa in allergic rhinitis. Ann Allergy 1982; 48: 184-6.

12. Bodger JN. Methylprednisolone acetate and its use in the treatment of students with hay fever at examination time. Curr Med Res Opin 1974; 2: 218-21.

13. Antonsen BJ. Behandling av pollenallergi hos barn med corticosteroiddepotreparat (Depo-Medrol). Tidsskr Nor Lægeforen 1968; 88: 1035-6.

14. Siegel C. The use of intramuscular triamcinolone acetonide in allergic rhinitis and other allergic conditions. Curr Ther Res Clin Exp 1965; 7: 625-32.

15. Brown EB, Seideman T, Siegelaub BA et al. Depomethylprednisone in the treatment of ragweed hay fever. Ann Allergy 1960; 18: 1321-30
16. Axelsson A, Lindholm B. The effect of triamcinolone acetonide on allergic and vasomotor rhinitis. Acta Otolaryngol 1972; 73: 64-7.

17. Laursen L, Faurschou P, Munch E. Intramuscular betamethasone injections vs topical beclomethasone and placebo in hay fever. Allergy 1988; 43: 424-30.

18. Borum P, Grønborg H, Mygind N. Seasonal allergic rhinitis and depot injection of a corticosteroid. Evaluation of the efficacy of medication early and late in the season based on detailed symptom recording. Allergy 1987; 42: 26-32.

19. Laursen LC, Faurschou P. Pals H et al. Intramuscular betamethasone dipropionate vs. oral prednisolone in hay fever patients. Allergy 1987; 42: 168-72.

20. McElhenney TR, Grater WC, Hines DW. Soluble injectable steroids in allergy. South Med J 1971; 64: $1455,64$.

21. Norsk legemiddelhandbok.

http://legemiddelhandboka.no/Legemidler/43981 (20.6.2010).

22. Legemiddelverket. www.legemiddelverket.no/ Legemiddelsoek/Sider/Preparatomtale.aspx? pakningld=906741df-5905-4b84-9494-

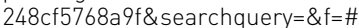
SPCHUMAN_04_03 (17.4.2013).

Mottatt 4.1. 2013, første revisjon innsendt 10.6. 2013, godkjent 7.11. 2013. Redaktør: Kristin Viste. 